\title{
Nurses: Workers Particularly Concerned by Contact Dermatitis in Public Hospital
}

\author{
Amira Omrane ${ }^{1^{*}}\left(\mathbb{D}\right.$, Charfeddine Amri $^{1}$, Lamia Bouzgarrou ${ }^{1}$ (D), Awatef Mahfoudh ${ }^{1}$, \\ Taoufik Khalfallah ${ }^{1}$, Mohamed Akrout ${ }^{1}$, Mohamed Adnene Henchi' ${ }^{1}$, Hichem Belhadj Ali ${ }^{2}$
}

\author{
${ }^{1}$ Department of Occupational Medicine and Ergonomics, Faculty of Medicine Monastir, Research Unit 12SP39, University of \\ Monastir, Monastir, Tunisia \\ ${ }^{2}$ Department of Dermatology, University Hospital of Monastir, Monastir, Tunisia \\ Email: *omraneamira@yahoo.fr
}

How to cite this paper: Omrane, A., Amri, C., Bouzgarrou, L., Mahfoudh, A., Khalfallah, T., Akrout, M., Henchi, M.A. and Ali, H.B. (2019) Nurses: Workers Particularly Concerned by Contact Dermatitis in Public Hospital. Open Journal of Nursing, 9, 313-328. https://doi.org/10.4236/ojn.2019.93030

Received: February 11, 2019

Accepted: March 25, 2019

Published: March 28, 2019

Copyright $\odot 2019$ by author(s) and Scientific Research Publishing Inc. This work is licensed under the Creative Commons Attribution International License (CC BY 4.0).

http://creativecommons.org/licenses/by/4.0/

\begin{abstract}
Background: Contact dermatitis is common disease and represents a significant problem in healthcare sector, mainly among nurses. Many studies reported the prevalence of contact dermatitis from different parts of the world. Nevertheless, data about its frequency in Tunisia especially in public hospital seems to be insufficient. This study aims to assess the prevalence of contact dermatitis among nurses working in public hospital and identify risk factors. Patient and Methods: A cross sectional study was conducted among a representative sample of 1278 health professionals working in a public hospital matched by professional status and department. The survey was based on a questionnaire, a specialized examination and patch tests. Results: The prevalence of occupational contact dermatitis was $22 \%$ (17.5 - 27.2). The worker profile at risk of contact dermatitis was a female nurse aged 37 years working in a surgical department during $12.7 \pm 9.36$ years. Hands were damaged in $92.4 \%$ of cases and rhythmicity with occupational exposure was reported by $86 \%$ of affected individuals. Patch tests using European Standard Battery were performed among 33 workers and revealed a sensitization to an allergen among 26 workers. Patch test using rubber battery (if suspicion of allergic contact dermatitis to gloves) was performed among 29 agents and positive among 12. The analytical study revealed that history of atopy, job tenure, the mean daily number of hand washing, the mean daily number of worn gloves and mean duration of glove wearing were significantly higher in the affected population. Conclusion: Contact dermatitis affects particularly nurses in public hospitals. Its prevention requires a diagnostic approach based on a detailed professional investigation and patch tests.
\end{abstract}




\section{Keywords}

Nurses, Contact Dermatitis, Public Hospital, Prevention

\section{Introduction}

Occupational dermatitis occupies an important place in the occupational disease. It is a topic in constant evolution. Occupational dermatitis is any skin abnormality caused or aggravated by the workplace [1]. It represents $20 \%$ to $30 \%$ of occupational diseases and $10 \%$ of dermatitis [1] [2].

In hospital, contact dermatitis (CD) is frequent with a prevalence ranging from $20 \%$ to $40 \%$ [3] [4] [5] [6]. CD observed among medical and paramedical staff represents $20 \%$ to $40 \%$ of all CD and ranks the third after the construction sector and the cleaning and maintenance professions [7].

In the health care settings, $\mathrm{CD}$ is caused by various allergens: rubber gloves, nickel of some instruments, drugs, antiseptics and disinfectants... [8]. The distribution of these allergens has changed considerably in recent years. Indeed, new substances have appeared in the field of diagnosis and care (antibiotics, neuroleptics), the field of hygiene (soaps, antiseptics, gloves) and maintenance (aldehydes, quaternary ammoniums) [9].

Many epidemiological studies reported that nurses are particularly at risk of $\mathrm{CD}$ in the health care settings [10]-[20]. The incidence of CD in nurses is ranging from $7 \%$ to $46 \%$ in different studies [11] [15] [21] [22].

This study aims to assess the prevalence of contact dermatitis among nurses working in public hospital and identify risk factors.

\section{Patients and Methods}

The study population included all non-administrative staff practicing in a public hospital in the center of Tunisia during at least one year. We included all medical and paramedical staff assigned to care activities and/or cleaning activities. We excluded medical or paramedical staff not practicing care activities or manipulating skin irritants or allergens (staff in charge of Consultations, those working in the Department of Occupational Medicine, Community Medicine or Physical and rehabilitation Medicine) administrative staff, maintenance workshop agents and ambulance attendants. Then the general population counted 1278 hospital staff (537 Nurses (42\%), 324 Doctors (25\%), 228 Senior Technicians (18\%) 127 Cleaning Workers (10\%) and 62 Auxiliary (5\%)). We performed a stratified random sampling matched by occupational grade and departments. This sample counted 300 hospital workers.

This is a cross-sectional study, performed in 2015, included:

- A questionnaire filled by the investigator, during a direct interview with workers. This interview was preceded by the explanation of the purpose of the study, anonymity procedure guarantee and the collection of the enligh- 
tened consent. This study was approved by the institutional ethics committee. The questionnaire contained 27 items referring to social and professional characteristics, personal and family history, clinical characteristics of dermatitis, occupational and non-occupational risk factors and additional tests performed (Annex 1).

- A dermatological examination performed in all symptomatic patients by a dermatologist for a detailed description and diagnosis of lesions.

- Patch tests performed in patients with suspected allergic contact dermatitis (ACD) using the European baseline series (EBS, TROLAB Patch test allergens), the specific series (rubber, disinfectants, perfumes, TROLAB Patch test allergens) and handled products brought by patients. Reading patch tests was carried out in day 2 and day 3 according to European Society of Contact Dermatitis guideline for diagnostic patch testing and following the recommendations of the International Contact Dermatitis Research Group (ICDRG) [23] [24].

The data collection and analysis was performed using the SPSS 18.0 software. We used the Chi-square test for qualitative variables with a significance threshold of $5 \%$. The comparison of the averages was made by the Student's $\mathrm{T}$ test with a significance level of $5 \%$.

\section{Results}

\section{1) Prevalence of CD:}

Sixty-six of the 300 participants in our study population had CD, accounting for a prevalence of $22 \%(17.53-27.20)$. Nurses were particularly affected and counted for $42 \%$.

The Socio-professional characteristics and occupational risk factors are presented in Table 1.

Patch tests were performed using the European baseline series (EBS), specific series and products handled by patients. The EBS was performed on 33 workers in whom ACD was suspected. Positivity to at least one allergen of EBS was noted among 26 patients. Three predominant allergens were identified: Nickel (18 cases, $6 \%$ of the study population ( $3.31-8.69)$ ), chromium (11 cases, $(3.66 \%$ (1.54 to 5.78$)$ ) and colbalt ( 9 cases, $3 \%$ (1.07 to 4.93$)$ ). They were followed by 4 cases positive to Paraphenylene diamine $(1.33 \%(0.003-2.63)), 3$ cases to the thiuram mix (1\%), 3 cases to benzocaine (1\%), 3 cases to N-Isopropyl-N-phenyl-4-phenylenediamine (1\%) and 3 cases to mercapto mix (1\%).

Tests to the rubber series were performed on 29 hospital workers for suspicion of ACD to gloves. It was positive on 12/29 participants. The 1,3-diphenylguanidine (DPG) was the most frequently positive allergen with a prevalence of $2 \%(0.21$ 3.11) (6 cases/13) followed by the Tetramethyl thiuram monosulfide (1\%) and the N Cyclohexyl benzothiazyl Sulphenamide (1\%). Seven hospital workers had a positive patch test to rubber series despite a negative test to rubber allergens contained in the EBS. 
Table 1. Socio-professional characteristics and occupational risk factors in the study population.

\begin{tabular}{|c|c|c|c|}
\hline Caracteristics & Mean & Minimal & Maximum \\
\hline Age & 38 years \pm 8.9 & 21 & 59 \\
\hline Sex & \multicolumn{3}{|c|}{ Males $=130(43.3 \%) ;$ Females $=170(56.7 \%)$, sex ratio $=0.76$} \\
\hline Occupational category & \multicolumn{3}{|c|}{$\begin{array}{c}127 \text { nurses }(42 \%), 75 \text { Doctors }(25 \%), 53 \text { senior technician }(18 \%) \text {, } \\
30 \text { blue-collar worker }(10 \%), 15 \text { medical auxiliary }(5 \%)\end{array}$} \\
\hline Speciality & \multicolumn{3}{|c|}{170 Medical (56.7\%), 130 surgical (43.3\%) } \\
\hline Job tenure. & 12.5 years \pm 9.3 & 1 year & 37 years \\
\hline Personal history of atopy & \multicolumn{3}{|c|}{106 (35.33\%): rhinitis $(18.3 \%)$} \\
\hline $\begin{array}{l}\text { Mean number of hand } \\
\text { washing/day }\end{array}$ & 7.3 times \pm 5.02 & 1 & 40 \\
\hline $\begin{array}{l}\text { Mean Number of borne } \\
\text { gloves/day }\end{array}$ & 3.2 pairs \pm 3.85 & 0 & 24 \\
\hline Duration of Wearing gloves & $0.6 \mathrm{~h} \pm 0.8$ & $0 \mathrm{~h}$ & $4 \mathrm{~h}$ \\
\hline Professional rhythmicity & \multicolumn{3}{|c|}{ Yes $=57$ personnel $/ 66(86 \%), \mathrm{No}=9 / 66$} \\
\hline
\end{tabular}

Patch tests to perfume series were performed in a nurse working in the bacteriology laboratory. The test to EBS was negative. Patch test to handled product; Alcogel ${ }^{\star}$ was positive (one cross). Patch tests to perfume series were positive to lemon grass oil.

Patch tests were performed using gloves on 23 hospital workers. A positive reaction was observed among 6 workers.

The Diagnosis of irritative contact dermatitis (ICD) was retained in 37 hospital workers (56\% of the affected population). The diagnosis of ACD was retained in 26 hospital workers (39\% of the affected population). Urticaria was diagnosed in 3 hospital workers (5\% of the affected population) (Table 2).

In the affected population, 22 hospital workers reported work-related contact dermatitis:

- 21 participants with $\mathrm{ACD} / 26: 13$ cases of $\mathrm{ACD}$ to gloves, 5 cases of $\mathrm{ACD}$ to disinfectants and 3 cases of ACD to metal medical instruments (Nickel, Cobalt).

- A worker suffered from contact urticaria to latex

Concerning the professional future, ninety-nine percent of affected workers kept the same workstation with changing of handling products, and/or wearing protective means. Two workers were mutated. Three nurses, auxiliary nursers and a senior technician changed their workstations in the same department.

\section{2) The risk factors of contact dermatitis:}

We performed an analytical study of risk factors of $\mathrm{CD}$ comparing the affected population $(n=66)$ and the non-affected population $(n=234)$. The family history of atopy, personal history of atopy, job tenure, the daily average number of handwashing, the daily average number of pairs of worn gloves and the average duration of wear were significantly higher in the affected population (Table 3 ). 
Table 2. Distribution of contact dermatitis in the study population according to the etiology.

\begin{tabular}{|c|c|c|c|}
\hline Type & Handled product & Staff & $\%$ \\
\hline \multirow[t]{4}{*}{ Urticaria } & Latex gloves & 1 & 0.33 \\
\hline & Parfun of a disinfectant (Clin'up $\left.{ }^{\star}\right)$ : lemon oil & 1 & 0.33 \\
\hline & Disinfectant Phagosept ${ }^{\star}$ spray (Biguanides) & 1 & 0.33 \\
\hline & Total & 3 & 1 \\
\hline \multirow[t]{11}{*}{ Eczema } & Gloves & 13 & 4.3 \\
\hline & Disinfectant & 5 & 1.05 \\
\hline & \multicolumn{3}{|l|}{-Formaldehyde $(\mathrm{n}=2)$} \\
\hline & \multicolumn{3}{|c|}{-Steranios, Cidex (Glutaraldehydes) + Clin'up ${ }^{\star}(\mathrm{n}=2)$} \\
\hline & \multicolumn{3}{|c|}{- Disinfectant $\left(\right.$ Alcogel $\left.^{*}\right)+$ parfum Lemonoil $(n=1)$} \\
\hline & Metal medical devices (nickel, cobalt) & 3 & 1 \\
\hline & Atopic & 2 & 0.66 \\
\hline & Nickel (previous relevance) jewellery & 1 & 0.33 \\
\hline & Benzocaine & 1 & .033 \\
\hline & Bleach(Chromium) & 1 & 0.33 \\
\hline & Total & 26 & 8.6 \\
\hline \multirow[t]{9}{*}{ Irritation } & Gloves & 23 & 7.6 \\
\hline & Disinfectant & 6 & 2 \\
\hline & \multicolumn{3}{|c|}{$\operatorname{Cidex}^{*}(\mathrm{n}=3)$, Alcogel $(\mathrm{n}=1)$, Clin'up $(\mathrm{n}=2)$} \\
\hline & Liquid soap & 3 & 1 \\
\hline & Antiseptic solution & 1 & 0.33 \\
\hline & Augmentin & 1 & 0.33 \\
\hline & Detergeant & 2 & 0.66 \\
\hline & Plastic & 1 & 0.33 \\
\hline & Total & 37 & 12.3 \\
\hline Total & & 66 & 22 \\
\hline
\end{tabular}

Table 3. Analytical study of risk factors for contact dermatitis.

\begin{tabular}{|c|c|c|c|}
\hline Characteristics & Affected population $n=66$ & Non-affected population $n=234$ & $\mathbf{P}$ \\
\hline Age & $37 \pm 8.9$ years & $38.2 \pm 8.8$ years & - \\
\hline Sex & Females $61 \%$ & Females $55.5 \%$ & - \\
\hline Family history of atopy & $54.5 \%$ & $32.9 \%$ & 0.001 \\
\hline Personal history of atopy & $51.5 \%$ & $30.7 \%$ & 0.002 \\
\hline Job tenure & $11.8 \pm 9.7$ years & $12.6 \pm 9.2$ years & - \\
\hline Surgical Speciality & $61 \%$ & $38.5 \%$ & 0.001 \\
\hline Mean number of hand washing/day & $8.5 \pm 4.9 /$ day & $6.9 \pm 4.9 /$ day & 0.017 \\
\hline Mean Number of borne gloves/day & $4.08 \pm 4.37 \mathrm{pairs} / \mathrm{day}$ & $2.95 \pm 3.6$ pairs/day & 0.036 \\
\hline Mean duration of glove Wearing/day & 1 hours \pm 1.3 & 0.5 hours \pm 0.6 & 0.003 \\
\hline
\end{tabular}




\section{Discussion}

This study aimed to assess the prevalence of contact dermatitis among nurses working in public hospital and identify risk factors. To meet this objectives, we conducted a cross sectional study among a representative sample of 1278 health professionals working in a public hospital. This sampling was only matched by professional status and department (medical or surgical one). The survey was based on a questionnaire, a specialized examination and patch tests. Otherwise, this study has some limitations that should be mentioned. In fact, it did not give an idea about the incidence of contact dermatitis. Moreover, patch tests were only among patients in the sampling with clinic argument of suspected allergic contact dermatitis. Thus only 33 patients were patch tested. This choice was justified by potential complications of this test [25] [26] [27].

In our study, the prevalence of CD was $22 \%(17.53 \%-27.20 \%)$. In Tunisia, the prevalence of occupational dermatitis among hospital workers is based on specific studies and ranges from $10 \%$ to $28.3 \%$ [28]. In Denmark, occupational dermatitis accounted for $16 \%$ of occupational diseases reported and ranked third [29]. Eczema and CD accounted for $94 \%$ - $98 \%$ of reported occupational dermatitis [29]. The incidence of occupational dermatitis among health care workers was estimated to be 7.3 cases/10,000 employees/year [29] [30]. Working in hospitals is classically described as a risk factor for hand dermatitis [31]. Indeed, the largest epidemiological study of hand dermatitis in general population, conducted in Sweden, reported an annual prevalence ranging from $9.7 \%$ to $11.8 \%$ [32]. This prevalence is higher among nursing staff (17\% - 30\%) [32]. Similarly, in this study, nurses were particularly affected by CD (42\%). Besides, several studies have noted that the prevalence of $\mathrm{CD}$ in nurses is probably due to their constant contact with drugs, anesthetics, antiseptics and their frequent wearing of gloves [33] [34].

In our study, $\mathrm{CD}$ concerned $17.3 \%$ of males and $23.5 \%$ of females. This difference was not statistically significant $(\mathrm{p}=0.46)$. According to the literature, many authors estimated that $\mathrm{CD}$ is more common among women [35]. In fact, gender may be considered as a predisposing factor to ACD, not because of differences in skin characteristics but due to an early exposure to allergens such as nickel [36]. In our study, the mean age of the affected population was lower than the non-affected population with no statistically significant differences. Sasseville [37] proved that young workers are prone to develop more occupational dermatitis due to their lack of experience or their non-compliance with safety instructions. In dentistry, Lee and al. reported an increase in the prevalence of $\mathrm{CD}$ with age among dentists [38]. Irritative contact dermatitis (ICD) is considered as a risk factor for developing ACD. This is related to the destruction of the skin barrier promoting the penetration of allergens, which increases the risk of ACD [35]. Consequently, small irritative lesions (even tiny) are warning signs for prompt action before ACD setup [39]. In our study, the history of atopy was significantly more frequent in the affected population. Working in the health 
care sector is a risk factor for the onset of dermatitis of the hands among atopic workers [40]. Some authors consider that the existence of a history of atopic dermatitis or a persistent atopic dermatitis is a risk factor to develop hand dermatitis. However, the absence of atopic manifestations (rhinitis, asthma) does not increase the risk of occupational dermatitis in hospitals [3]. Moreover, Atopic subjects also have a higher risk of developing contact urticaria (latex, amylase, food proteins) [41]. In our study, $72.7 \%$ of the affected population (48/66 cases) reported regular cleaning activities. This rate was about $47 \%$ $(141 / 234$ cases $)$ in the non-affected population. The difference was not statistically significant $(\mathrm{p}=0.064)$. Cleaning activities expose to the irritative effect of water, detergents and disinfectants. Moreover, leisure activities expose to various allergens and irritants such as sports activities (gloves, sportswear...), gardening (plants, insecticides, pesticides) and handiwork (cement, paint, varnish...) [42]. Medical examination should specify the products to which the subject is exposed to while practicing extra-professional activities [42].

In our study, the difference between the average job tenure in the affected and non-affected population was not statistically significant $(\mathrm{p}=0.54)$. In nursing, the occurrence of hand lesions is higher during the first three months after recruitment [15] [25]. This can be explained by the phenomenon of "hardening", that is the gradual tolerance of the tegument to irritative substances [43]. In our study, the prevalence of CD was significantly higher in surgical departments ( $\mathrm{p}=$ 0.001). Some authors found that the most affected are those working in Pediatrics and Obstetrics and Gynecology departments and attributed this to the frequent wearing of latex protective gloves and excessive hand washing [28]. Wet work can be defined as any activity which involves exposing the skin to aqueous substances for more than 2 hours per day or a wearing water proof gloves for over 2 hours per day or washing hand frequently (more than 20 times per day or even less if the procedure is more aggressive) [41]. In our study, the average daily number of hand washing was significantly higher in the affected population $(8.5 \pm 4.9$ loads per day) than in the non-affected population $(6.9 \pm 4.9$ daily washing) ( $p=0.017)$. Frequent hand washing is a risk factor of the onset of dermatitis of the hands especially because of repeated irritation and use of antiseptics and disinfectants [44]. Hand cleaning products mainly cause irritation but rarely allergic contact eczema secondary to surfactants, preservatives, disinfectants, fragrances and/or other additives (such as lanolin, colophony, metals...) [44]. Some studies have shown that skin exposure to soap and water causes more irritation that the use of antiseptic alcohol solutions among health workers [32]. Exposure to irritants is mainly related to frequent handwashing rather than wet work [45]. In our study, all the subjects in the affected population declared wearing gloves during work versus $91.4 \%$ in the non-affected population. The average number of pairs of gloves used per day was significantly higher in the affected population $(4.08 \pm 4.37$ pairs $)$ than in non-affected one $(2.95 \pm 3.6$ pairs) $(\mathrm{p}=0.036)$. In the study of Lindberg [33], 85\% of the dental staff regularly 
wear gloves, and $14.8 \%$ of them use more than 60 pairs of gloves per week. The average duration of gloves worn per day was higher in affected individuals $(1 \pm$ 1.3 hours) compared with non-affected subjects ( $0.5 \pm 0.6$ hours). This difference was statistically significant $(\mathrm{p}=0.003)$. In a Swedish study of 3083 dentists, $73 \%$ reported wearing gloves for longer than two hours per day and $48 \%$ for more than 6 hours per day [46].

The prevalence of ACD to gloves in medical and paramedical staff in our study was equal to $4.3 \%$ (4.27 to 4.32 ). Patch tests to rubber series were positive in 6 agents/13 (46.1\%). Moreover, tests to the EBS showed positivity to Thiuram mix ( 3 cases), to paraphenylene diamine ( 3 cases), to the mercapto mix ( 2 cases) and to mercapto benzothiazole ( 2 cases). Tests to the EBS did not show positivity to rubber allergens in 6 cases of eczema to gloves. In these cases, tests to rubber series were positive to the 1.3 Diphenyl guanidine. This could justify the proposal to add the 1,3 Diphenyl guanidine to allergens of the EBS. In fact, the 1,3-diphenyl guanidine allergen was the most provider of positive patch tests to rubber series with (6 cases) a prevalence of $2 \%$ in the study population. These findings are compatible with those of Piskin's study [47]. Whereas, some other studies reported that thiurams and carbamates were the most frequently incriminated as rubber allergens [48]. The 1,3-diphenyl guanidine is an allergen belonging to the guanidines family which was responsible for positive tests in 1.9\% of patients tested in the study of IVDK [49]. According to Piskin [47], the 1,3-diphenyl guanidine is used in industrial products than in latex consumer products. He explained the increase in sensitivity to 1,3-diphenyl guanidine in his study by the preventive efforts that have reduced the use of latex gloves in his hospital, at the expense of synthetic rubber gloves that contain the 1,3-diphenylguanidine [47].

\section{Conclusion}

In conclusion, contact dermatitis is frequent among nurses working in public hospitals. This study emphasizes the necessity of a preventive approach of hand dermatitis since recruitment.

\section{Acknowledgements}

\section{Financial Disclosure}

This study was not funded.

\section{Conflict of Interest}

All authors agree with the content of the manuscript. There are no conflicts of interests between or among authors.

\section{Ethical Approval}

This article does not contain any studies with animals performed by any of the 
authors. All participants gave informed consent for the research and their anonymity was preserved. This study was approved by the institutional ethics committee.

\section{References}

[1] Alchorne Ade, O., Alchorne, M.M. and Silva, M.M. (2010) Occupational Dermatosis. Anais Brasileiros de Dermatologia, 85, 137-145; quiz 146-147.

[2] Géraut, C. and Tripdi, D. (1997) Prévention des dermatoses professionnelles allergiques d'origine chimique. Revue Française d'Allergologie et d' Immunologie Clinique, 37, 287-296. https://doi.org/10.1016/S0335-7457(97)80161-X

[3] Barbaud, A. (2005) Dermatoses professionnelles en milieu hospitalier. Revue Française d Allergologie et d Immunologie Clinique, 45, 252-256. https://doi.org/10.1016/j.allerg.2005.02.004

[4] Smit, H.A. and Coenraads, P.J. (1993) A Retrospective Cohort Study on the Incidence of Hand Dermatitis in Nurses. International Archives of Occupational and Environmental Health, 64, 541-544. https://doi.org/10.1007/BF00517697

[5] Stingenie, L., Lapomarda, V. and Lisi, P. (1995) Occupational Hand Dermatitis in Hospital Environments. Contact Dermatitis, 33, 172-176. https://doi.org/10.1111/j.1600-0536.1995.tb00540.x

[6] Henchi, M.A., Belhaj Ali, H., Chaari, N., Abdallah, B., et al. (2006) Apport des explorations allergologiques dans le diagnostic des dermatoses de contact professionnelles en milieu hospitalier. Archives des Maladies Professionnelles et de P Environnement, 67, 356-357. https://doi.org/10.1016/S1775-8785(06)78212-1

[7] Mehl (1977) Pathologie professionnelle des professions médicales et para-médicales. Encyclo Méd Chir Paris 9, Toxicologie-Pathologie professionnelle $16545 \mathrm{~A}^{10}$.

[8] Foussereau, J. (1991) Allergènes responsables d'eczéma en milieu de travail. Doc Méd Trav $1^{\text {er }}$ trimestre, 45, 1-11.

[9] Gargouri, I., Fantoni, S., Masmoudi, M.L., Gharbi, R. and Frimat, P. (2002) Allergènes en milieu de soins: Etiologie, épidémiologie et manifestations cliniques. Revue Française d Allergologie et d Immunologie Clinique, 42, 178-192. https://doi.org/10.1016/S0335-7457(01)00133-2

[10] van der Burg, C.K., Bruynzeel, D.P., Vreeburg, K.J., von Blomberg, B.M. and Scheper, R.J. (1986) Hand Eczema in Hairdressers and Nurses: A Prospective Study. I. Evaluation of Atopy and Nickel Hypersensitivity at the Start of Apprenticeship. Contact Dermatitis, 14, 275-279. https://doi.org/10.1111/j.1600-0536.1986.tb05275.x

[11] Molin, S., Bauer, A., Schnuch, A. and Geier, J. (2015) Occupational Contact Allergy in Nurses: Results from the Information Network of Departments of Dermatology 2003-2012. Contact Dermatitis, 72, 164-171. https://doi.org/10.1111/cod.12330

[12] Supapvanich, C., Povey, A.C. and de Vocht, F. (2013) Respiratory and Dermal Symptoms in Thai Nurses using Latex Products. Occupational Medicine (Lond), 63, 425-428. https://doi.org/10.1093/occmed/kqt068

[13] Mack, S. (2004) Atopic Dermatitis: An Overview for the Nurse Practitioner. Journal of the American Association of Nurse Practitioners, 16, 451-454. https://doi.org/10.1111/j.1745-7599.2004.tb00423.x

[14] Ozyazicioğlu, N., Sürenler, S. and Tanriverdi, G. (2010) Hand Dermatitis among Paediatric Nurses. Journal of Clinical Nursing, 19, 1597-603. 
https://doi.org/10.1111/j.1365-2702.2010.03194.x

[15] Akan, A., Toyran, M., Erkoçoğlu, M., Kaya, A. and Kocabaş, C.N. (2012) The Prevalence of Allergic Contact Sensitization of Practicing and STUDENT Nurses. International Journal of Occupational and Environmental Medicine, 3, 10-18.

[16] Noonan, A. and Moyle, M. (2005) Nurses and Occupational Contact Dermatitis. Australian Nursing Journal, 12, 29-31.

[17] Lee, Y.J., Park, S., Kim, J.Y., Kim, C.G. and Cha, S.K. (2013) Clinical Nurses' Knowledge and Visual Differentiation Ability in Pressure Ulcer Classification System and Incontinence-Associated Dermatitis. Journal of Korean Academy of Nursing, 43, 526-535. https://doi.org/10.4040/jkan.2013.43.4.526

[18] Chen, J., Gomez, P., Kudla, I., DeKoven, J., Holness, D.L. and Skotnicki, S. (2016) Return to Work for Nurses with Hand Dermatitis. Dermatitis, 27, 308-312. https://doi.org/10.1097/DER.0000000000000215

[19] Visser, M.J., Verberk, M.M., Campbell, L.E., McLean, W.H., Calkoen, F., Bakker, J.G., van Dijk, F.J., Bos, J.D. and Kezic, S. (2014) Filaggrin Loss-of-Function Mutations and Atopic Dermatitis as Risk Factors for Hand Eczema in Apprentice Nurses: Part II of a Prospective Cohort Study. Contact Dermatitis, 70, 139-150.

https://doi.org/10.1111/cod.12139

[20] Drucker, A.M., Li, W.Q., Lin, L., Cho, E., Li, T., Camargo Jr., C.A. and Qureshi, A.A. (2016) Atopic Dermatitis (Eczema) in US Female Nurses: Lifestyle Risk Factors and Atopic Comorbidities. British Journal of Dermatology, 174, 1395-1397. https://doi.org/10.1111/bjd.14373

[21] Chew, A.L. and Maibach, H.I. (2003) Occupational Issues of Irritant Contact Dermatitis. International Archives of Occupational and Environmental Health, 76, 339-346. https://doi.org/10.1007/s00420-002-0419-0

[22] Szepietowski, J. and Salomon, J. (2005) Hand Dermatitis: A Problem Commonly Affecting Nurses. Roczniki Akademii Medycznej w Bialymstoku, 50, 46-48.

[23] Alikhan, A., Cheng, L.S., Ale, I., Andersen, K.E., Bruze, M., Eun, H.C., et al. (2011) Revised Minimal Baseline Series of the International Contact Dermatitis Group (ICDRG): Evidence Based Approach. Dermatitis, 22, 121-122.

[24] Johansen, J.D., Aalto-Korte, K., Agner, T., Andersen, K.E., Bircher, A., Bruze, M., et al. (2015) European Society of Contact Dermatitis Guideline for Diagnostic Patch Testing-Recommendations on Best Practice. Contact Dermatitis, 73, 195-221. https://doi.org/10.1111/cod.12432

[25] Castelain, M. (2009) Effets secondaires, complications et contre-indications des patch-tests. Annales de Dermatologie et de Vénéréologie, 136, 645-649. https://doi.org/10.1016/j.annder.2009.06.010

[26] Lachapelle, J.-M. (2011) Historical Aspects. In: Johansen, J.D., Frosch, P.J. and Lepoittevin, J.-P., Eds., Contact Dermatitis, Springer, Berlin, Heidelberg, 1-9.

[27] Thielitz, A. and John, S.M. (2016) Occupational Contact Dermatitis. In: Johansen, J.D., Lepoittevin, J.-P. and Thyssen, J.P., Eds., Quick Guide to Contact Dermatitis, Springer-Verlag, Berlin, Heidelberg, 103-114.

[28] Lejri, N. (2001) Contatc Dermatitis among Nurses: Epidemiological Study Performed in Public Hospital Farhat Hached Sousse. Thèses, Faculty of Medicine, Sousse, Tunisia.

[29] Crépy, M.N. (2003) Le point sur les dermatoses professionnelles. Revue Française d Allergologie et d' Immunologie Clinique, 43, 113-119. https://doi.org/10.1016/S0335-7457(02)00035-7 
[30] Dhivert-Donnadieu, H., Demoly, P. and Hemery, M.-L. (2006) Introduction aux allergènes professionnels des métiers de soins. Revue Française d Allergologie et d'Immunologie Clinique, 46, S40-S44.

[31] Dickel, H., Kuss, O., Schmidt, A., Kretz, J. and Diepgen, T.L. (2002) Importance of Irritant Contact Dermatitis in Occupational Skin Disease. American Journal of Clinical Dermatology, 3, 283-289. https://doi.org/10.2165/00128071-200203040-00006

[32] Kampf, G. and Löffler, H. (2003) Dermatological Aspects of a Successful Introduction and Continuation of Alcohol-Based Hand Rubs for Hygienic Hand Disinfection. Journal of Hospital Infection, 55, 1-7. https://doi.org/10.1016/S0195-6701(03)00223-8

[33] Lindberg, M. and Silverdahl, M. (2000) The Use of Protective Gloves and the Prevalence of Hand Eczema, Skin Complaints and Allergy to Natural Rubber Latex among Dental Personnel in the County of Uppsala, Sweden. Contact Dermatitis, 43, 4-8. https://doi.org/10.1034/j.1600-0536.2000.043001004.x

[34] Silverberg, J.I., Patel, N., Immaneni, S., Rusniak, B., Silverberg, N.B., Debashis, R., Fewkes, N. and Simpson, E.L. (2015) Assessment of Atopic Dermatitis Using Self-Report and Caregiver Report: A Multicentre Validation Study. British Journal of Dermatology, 173, 1400-1404. https://doi.org/10.1111/bjd.14031

[35] Nettis, E., Colanardi, M.C., Soccio, A.L., Ferrannini, A. and Tursi, A. (2002) Occupational Irritant and Allergic Contact Dermatitis among Healthcare Workers. Contact Dermatitis, 46, 101-107. https://doi.org/10.1034/j.1600-0536.2002.460208.x

[36] Modjtahedi, B.S., Modjtahedi, S.P. and Maibach, H.I. (2004) The Sex of the Individual as a Factor in Allergic Contact Dermatitis. Contact Dermatitis, 50, 53-59. https://doi.org/10.1111/j.0105-1873.2004.00299.x

[37] Sasseville, D. (2013) La dermatite de contact professionnelle. Encyclopédie de Sécurité et de Santé au Travail, 12, 10-15.

[38] Lee, J.Y., Yoo, J.M., Cho, B.K. and Kim, H.O. (2001) Contact Dermatitis in Korean Dental Technicians. Contact Dermatitis, 45, 13-16. https://doi.org/10.1034/j.1600-0536.2001.045001013.x

[39] Crépy, M.N. (2006) Dermatoses professionnelles: aide au diagnostic dermatologique. Document pour le médecin du travail $2^{\text {ime }}$ Trimestre, 106, 219-220.

[40] Beaudoin, E., Kanny, G., Moneret-Vautrin, D.A., et al. (2001) Epidémiologie des maladies allergiques en l'an 2000. Archives des Maladies, 62, 493-494.

[41] Doutre, M.S. (2005) Urticaire et dermite de contact aux protéines en milieu professionnel. Revue Française d Allergologie et dimmunologie Clinique, 45, 248-251. https://doi.org/10.1016/j.allerg.2005.02.008

[42] Yassin, M.S., Lierl, M.B., Fisher, T.J., O’Brien, K., et al. (1994) Latex Allergy in Hospital Employees. Annals of Allergy, 72, 245-249.

[43] Lachapelle, J.M. and Ben Jemâa, A. (1989) Evaluation clinique et para clinique de l'irritation cutanée. 10e Cours d'Actualisation en Dermato-Allergologie. GERDA, $2-13$.

[44] Crépy, M.N. (2005) Dermatoses professionnelles aux détergents. Document pour le médecin du travail, 103, 375-384.

[45] Jungbauer, F.H.W., Lensen, G.J., Groothoff, J.W. and Coenraads, P.J. (2004) Exposure of the Hands to Wet Work in Nurses. Contact Dermatitis, 50, 225-229. https://doi.org/10.1111/j.0105-1873.2004.0314.x

[46] Wrangsjo, K., Wallenhammar, L.M., Ortengren, U., Barregard, L., Andreasson, H., 
et al. (2001) Protective Gloves in Swedich Dentistry: Use and Side-Effects. British Journal of Dermatology, 145, 32-37.

https://doi.org/10.1046/j.1365-2133.2001.04278.x

[47] Piskin, G., Meijs, M.M., Van Der Ham, R. and Bos, J.D. (2006) Glove Allergy Due to 1,3-Diphenylguanidine. Contact Dermatitis, 54, 61-62.

https://doi.org/10.1111/j.0105-1873.2006.0729d.x

[48] Knudsen, B., Lerbaek, A., Johansen, J.D. and Menne, T. (2006) Reduction in the Frequency of Sensitization to Thiurams. A Result of Legislation? Contact Dermatitis, 54, 170-171. https://doi.org/10.1111/j.0105-1873.2005.0739c.x

[49] Geier, J., Lessmann, H., Uter, W. and Schnuch, A. (2003) Occupational Rubber Glove Allergy: Results of the Information Network of Departments of Dermatology (IVDK), 1995-2001. Contact Dermatitis, 48, 39-44.

https://doi.org/10.1034/j.1600-0536.2003.480107.x 


\section{Annex 1: Survey Sheet in Dermatology Allergology}

\section{I-Caractéristiques socioprofessionnelles:}

Nom:

Prénom:

Age:

Sexe: 1-Masculin, 2-Féminin

Statu matrimonial: 0-célibataire, 1-marié,

2-divorcé, 3-veuf

I_I

Côté dominat: 1-droitier 2-gaucher

3-ambidextre

I_I

Service: (code).

I_I

Ancienneté professionnelle (années)

II-Antécédents:

1-Familiaux allergiques:

1-Dermatite atopique

2-Urticaire

3-Eczéma

2-personnels non allergiques

a) Cutanés:

1-Psoriasis

2-Ulcère de jambe

3-Mycose

b) Non cutanées:

1-diabète

3-endométriose

4-soins dentaires

3-Personnels allergiques:

$$
\begin{aligned}
& \text { 1-Dermatite atopique } \\
& \text { 2-Urticaire } \\
& \text { 3-Eczéma }
\end{aligned}
$$

4-Habitudes:

Tabac: (PA)

1_oui

Alcool:

1-Oui

5-Activité extra professionnelle:

1-Activité ménagère

2-Entretien de voiture

3-Entretien de maison Si oui produits manipulés:

1-Détergents

2-Peinture

3-Ciment

\section{III-Clinique:}

1-Poids:

2-Taille

3-BMI

2-Signe Fonctionnel

1-Prurit 2-Brûlures

4-conjonctive

5-Asthme

6-Rhinite

7-Absence

4-Dermite irritative

5-Autres...

6-Absence

2-HTA

3-cancer du sein

4-Autres

4-Conjonctivite

5-Asthme

6-Rhinite

7-Absence

2-non

3-NP

I_I

2-Non

3-NP

I_I

4-Jardinage

5-Autre.....

6-Absence

4-Pesticides-insecticides

5-Autres:.

6-Absence
3-Douleur
4-Absence 
3-Lésions cutanées

$$
\text { 1-Oui 2-Non }
$$

Si non:

Début après embauche:

$$
\begin{aligned}
& 1-<6 \text { mois } \\
& \text { 2-6à12ans }
\end{aligned}
$$

Type:

$$
\begin{aligned}
& \text { 1-Erythème } \\
& \text { 2-Papule } \\
& \text { 3-Vésicule }
\end{aligned}
$$

Topographie:

$$
\text { 1-Localisée }
$$

$$
\text { 1-Zone de contact }
$$

Localisation:
a) Tête:
1-Oui
Si oui:
1-Cuir chevelu
4-Paupières
b) Cou:
1-Oui
c) Tronc:
1-Oui
d) Mains:
1-Oui
Si oui:
1-Dominante
Siège:
1-Doigts
2-Ongles
e) Poignet:
1-Oui
Si oui:
1-Face antérieure
f) Bras et avant bras:
1-Oui
g) Cuisses et jambes:
1-Oui
h) Pieds:
1-Oui
Si oui:
1-Dos du pied

\section{IV-Facteurs professionnels:}

1-Rythme professionnel: 1-Oui

2-Collègues de travail atteints: 1-Oui

3-Lavage des mains au travail ( $\mathrm{nb} / \mathrm{j})$ :

4-Produit de lavage des mains:

1-Savon

3-Désinfectant

5-Port de gants:

1-Oui

Si oui: type: 1-Latex

$$
\text { 2-Caoutchouc }
$$

Si latex: nombre de paires/j

Durée moyenne du port de gants $(\mathrm{h}) / \mathrm{j}$

6-Produits Manipulés suspecté:

3-1à3ans

4->3ans

4-Suintement

5-Hyper kératose et/ou fissures

6-Urticaire

7-Squames

2-Diffuse

2-Zone découverte

3-Autre:

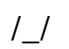

2-Non

2-Front

5-Oreilles

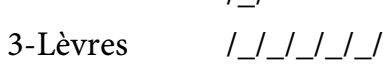

6-Nez

2-Non

2-Non

I_I

I_I

2-Non

I_I

2-Non dominante

3-Dos des mains

3-Les deux I_I

4-Paume

2-Non

2-Face postérieure

2-Non

2-Non

2-Non

2-Plante du pied

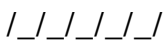

3-Les deux I_/

2-Non

I_I

2-Non

3_NP

I_I

2-Savon liquide

I_I_

I_I

4-Autres:.

2-Non

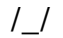

3-Cuir

4-Vinyle

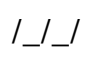

5-Autre: préciser 


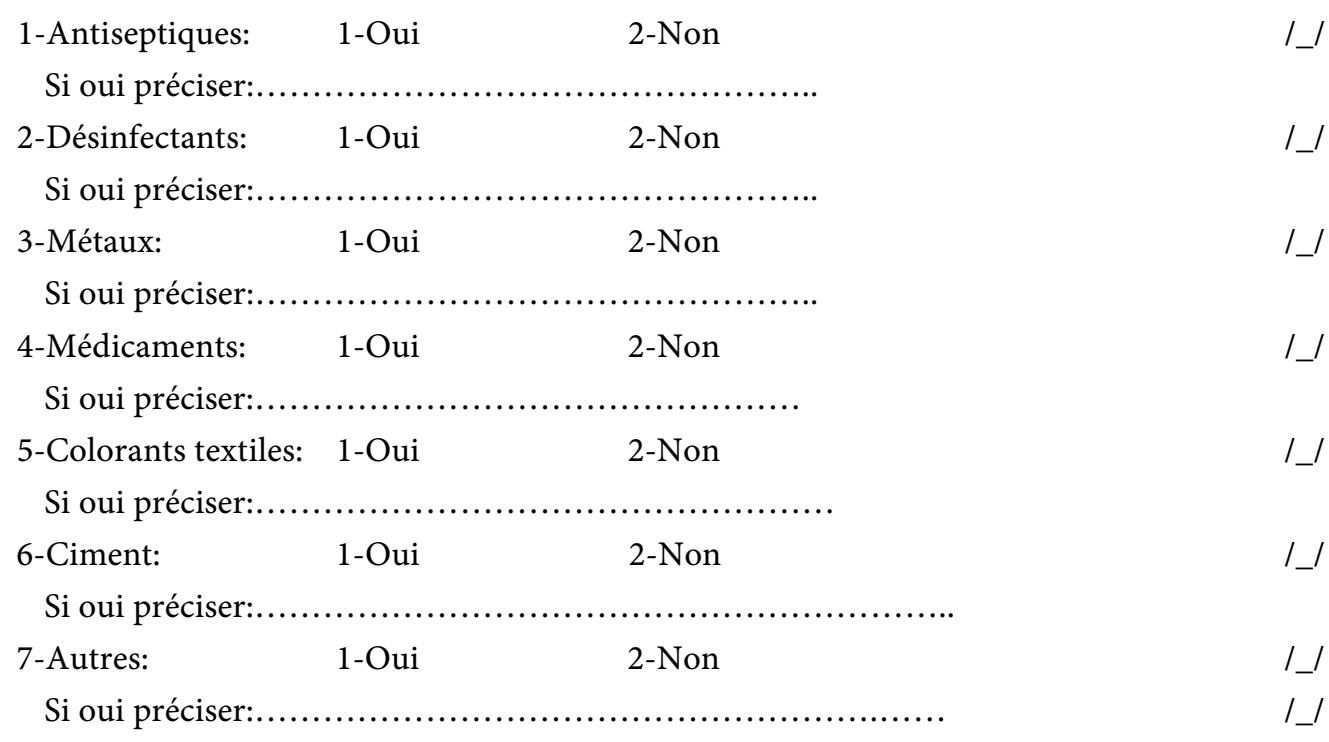

V- Facteurs extra professionnels et vestimentaires suspectés:

$\begin{array}{ll}\text { 1-Tissu } & \text { 6-Bijoux de fantaisie } \\ \text { 2-Caoutchouc } & \text { 7-Parfum } \\ \text { 3-Cuir } & \text { 8-Maquillage } \\ \text { 4-Plastique } & \text { 9-Autres.................... } \\ \text { 5-Métaux } & \text { 10-Absence }\end{array}$

\section{VI- Patch tests:}

1-Batterie standard:

1-Oui

2-Non

I_I

Si oui

1- Réaction positive

I_I

2- Réaction négative

3- Réaction douteuse

Si positive, préciser

( $\mathrm{n}^{\circ}$ du produit)

I_/_/_/_II

2-Autres Batteries:

1-Oui

2-Non

I_I

Si oui, préciser la batterie spécifique

Si oui

1- Réaction positive

2- Réaction négative

3- Réaction douteuse

Si positive, préciser

( $\mathrm{n}^{\circ}$ du produit $)$

VII-Diagnostic:

1-Irritation

2-Eczéma

3-Urticaire

I_I

a-manu porté

b-aéroporté

c-photo sensible

VIII-Etiologies:

Type:
1- Professionnelle

1-Médicamenteuse

2-Alimentaire

3-Produits ménagers
2- Non professionnelle 3-Mixte

4-Vestimentaire

5-Cosmétique

6-Autre: 


\section{IX-Conduite:}

1-Oui

2-Non

I_I

Si oui, $\mathrm{n}^{\circ}$ tableau.

agent.

I_II

2-Devenir professionnel:

1-Changement de poste (même service)

2-Mutation de service

3-Même poste

3-Mesure préventive:

1-Changement de produit incriminé

2-Port de moyen de protection

3-Pas de mesures préventives 